\title{
防波堤に作用する重複波圧の推定精度の 定量的評価に関する研究
}

\author{
高木 泰士 1 中島 ちひろ2 \\ 1正会員 横浜国立大学特別研究教員 環境情報研究院（广240-8501横浜市保土ヶ谷区常盤台79-5） \\ E-mail:htaka@ynu.ac.jp \\ 2非会員大田区まちづくり推進部まちづくり課（テ144-0052大田区蒲田5-13-14）
}

\begin{abstract}
海岸や海洋構造物を合理的に設計するためには, 信頼性の高い推定手法を用いて波圧を推定することが 重要であることは言うまでもないが, 荷重と抵抗力の各変動特性を考慮した設計法である信頼性設計法が 今後この分野において普及していくことを考えると, 事前に適用可能な波圧推定手法の精度を定量的に評 価しておく必要がある. 本研究では, 大水深に設置される防波堤において支配的な外力となる重複波圧に 着目して, その有力な推定手法と期待される有限振幅重複波理論に基づく第4次近似解の推定精度の定量 的な評価を水理模型実験の結果との比較に基づいて試みた。その結果, 実験值と計算值の比は平均 0.91 , 標準偏差 0.10 という変動特性値が得られ，また両者の関係性は正規分布で近似可能であることがわかった.
\end{abstract}

Key Words : reliability based design, fourth order approximation to the pressure of standing waves, statistical uncertainty, breakwater in deep water, hydraulic model test

\section{1. 目的}

近年，埋立地の沖合展開や施工技術の向上などに伴つ て，防波堤や護岸等の海岸・港湾構造物は大水深域にお いても建設されるようになった. 一般的に，このような 大水深に設置される構造物は, 波浪に対寸る安定性を十 分に確保するため大断面になりやすく，また良質な石材 等を大量に使用するため, コストは比較的浅い地点に設 置される構造物と比較して相当に割高となる場合が多い 一方で設計体系が性能設計へと大きく移行しつつある現 在, 構造物の安定性とコストの両面に関して合理的な設 計断面を得るための研究が各方面で積極的に推進されて いる. 今回対象とする防波堤については，滑動等の変形

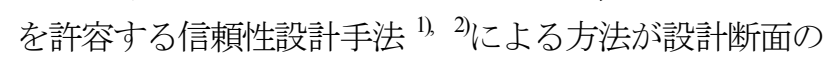
合理化に大きく貢献するものと期待されている. しかし, 過去の防波堤の信頼性設計に関する研究は, 比較的水深 が浅く，砕波が支配的となるような地点に設置される防 波堤を対象としている場合がほとんどであり，冒頭で述 べたような大水深域を対象とした研究は十分に行われて いないのが現状である.

最近，高木·柴山核は，重複波の作用が支配的となる大 水深域に設置される防波堤に関して，レベル3信頼性設 計法に基づく設計手法を提案しており，今後は設置水深 を問わず，合理的な設計に向けた研究が促進されること
が期待される.

本研究では, このような大水深域の防波堤断面に最も 支配的な影響を与えると考えられる重複波圧の計算精度 について，水理模型実験結果との比較を行ってその精度 の検証を行い，同時にレベル3信頼性設計法において必 要となる推定精度の変動特性について定量的な評価を試 みる。

\section{2. 有限振幅重複波理論に基づく重複波圧の近似解}

大水深域における波圧の計算には，高木・柴山离がレベ ル3信頼性設計法の中で適用した合田・柿崎 ${ }^{4} の$ 有限振幅 重複波理論に基づく修正第4次近似解（以下，第4次近似 解）が今後有力な算定手法になり得るものと考える. そ の理由は，この手法を用いることで波圧の最大值だけで はなく，その時間変化についても計算が可能になるため である. 従来の許容応力度設計法に基づく設計では, 基 本的には波力の最大值のみを考慮していたけれども，今 後の性能設計においては構造物の変形を予測することが 重要となり, このため波圧については最大值に加えて, その時間変化も重要となってくる.

合田・柿崎 ${ }^{4}$ のモデルに代表される有限振幅重複波理論 に基づく高次近似解については, Tsuchiya and Yamaguchi' やMallyachari and Sundar)等により適用限界や精度につい 
ての検証が行われており，通常の波浪条件に対して十分 な精度を有することが既に確認されている.

図-1および図-2にNagai ${ }^{7)}$ の実験結果と今回使用するモ デルによる第4次近似解の計算結果の比較を示す. 図中 には参考のため線形近似解による結果も示している.

図-1の波形勾配が比較的緩やかなケースおよび図-2の 比較的急なケースのいずれにおいても第4次近似解の計 算結果は実験結果を精度良く再現できていることがわか る. 特に, 波形勾配や相対水深が大きくなると, 高次成 分の影響が顕著となり, 図-2の実験結果が示す通り, 波 圧の峰が分裂して双峰型の波圧波形が現れてくるが，第 4次近似解はこのような重複波の特徵を十分に再現でき ている.

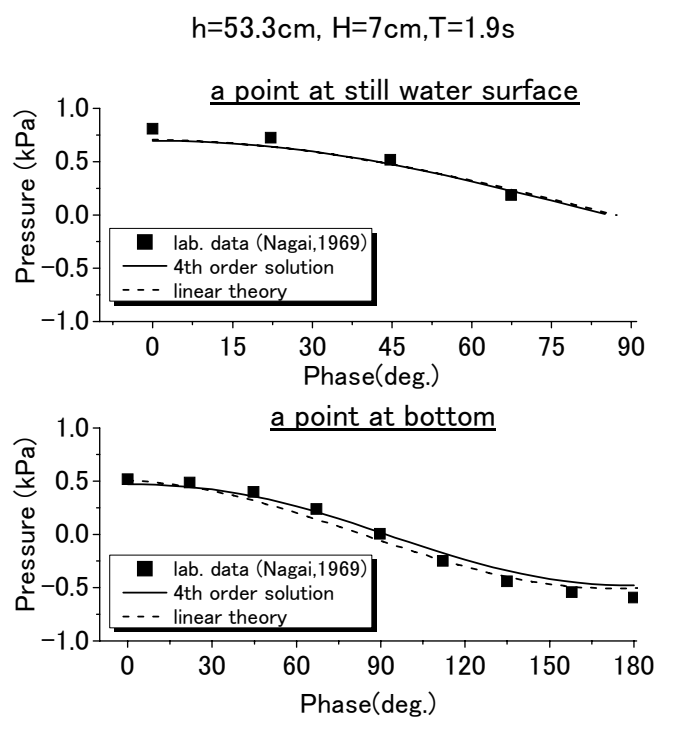

図-1 実験值と第4次近似解の比較 $(H / L=0.018, h / L=0.133)$

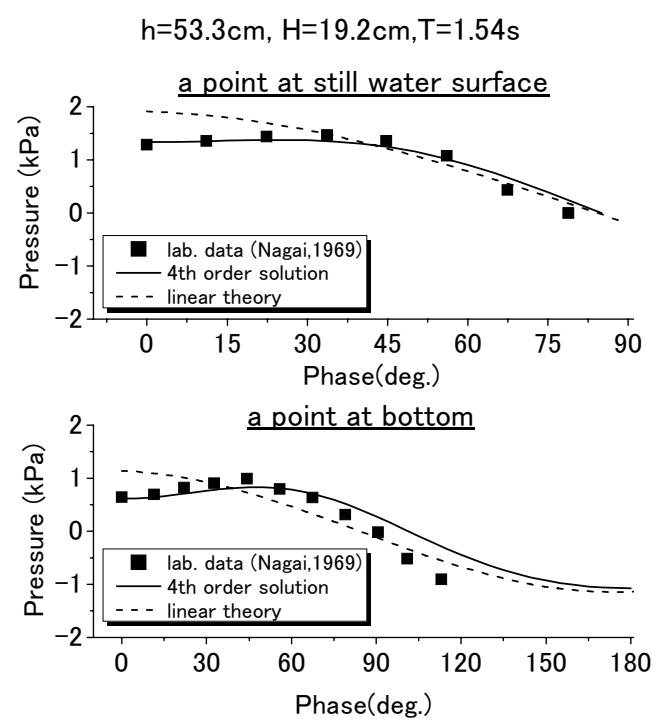

図-2 実験值と第4次近似解の比較 $(H / L=0.065, h / L=0.181)$

\section{3. 水理模型実験による重複波圧の計測}

以上の通り, 定性的には第4次近似解が実際の設計に も応用できる程度の精度を有することがわかる。しかし， 今後構造物の性能評価のツールとして有力と考えられて いる信頼性設計法では，外力や抵抗力の各成分は確率的 な変動量として定義されるため, 設計において必要とな る推定精度の確率的な変動特性值を把握しておく必要が ある、そこで，変動特性值の目安を取得する目的のため， 水理模型実験により防波堤直立部に作用する波圧を計測 して, 計算值との比較を行う。

\section{(1) 実験装置およびケーソン式防波堤模型}

実験には横浜国立大学所有の反射波吸収制御機能を備 えたピストン型造波装置を使用した。水路は全長 $17 \mathrm{~m}$, 幅0.6mであり，造波板より約 $10 \mathrm{~m}$ の地点に図-3に示すケ ーソン式防波堤の模型を設置した。防波堤の設置水深は 現地スケールで $20 \mathrm{~m}$ と想定して，実験スケールが $1 / 100$ と なるように防波堤の断面寸法を決定した. 現地の状況を 出来る限り再現するため, 中央粒径 $0.2 \mathrm{~mm}$ 程度の砂で原 地盤を模擬し, その上に粒径 $10 \mathrm{~mm}$ 以下(現地換算 $1 \mathrm{~m}$ 以 下)の砕石を使用してマウンドを配置した。ケーソンは アクリルを使用して製作し，圧力計測中に滑動しないよ うに中詰砂として砂鉄を使用して十分な重量を確保した.

\section{(2) 実験条件およびデータ処理}

ケーソン及び捨石マウンドが設置されていない状態で 通過波高検定を実施して，波高4.2〜 $12.1 \mathrm{~cm} ，$ 周期 0.8 , 1.0，1.2，1.4sの合計26ケースの波浪条件を設定した。こ のため，実物スケールでは $H_{\max }=4.2 \sim 12.1 \mathrm{~m}\left(H_{13} \fallingdotseq\right.$ $\left.H_{\max } 1.6=2.6 \sim 7.6 \mathrm{~m}\right), T_{\max }=8 \sim 14 \mathrm{~s}$ となり, 内湾, 外洋いず れに設置される防波堤にも適用可能と考える. 圧力計測 のためにひずみ変換式圧力計を静水面より $6,10,14 \mathrm{~cm}$ の3箇所に配置した．なお，圧力計は同じ水深に3個並列 配置してサンプリング周波数 $50 \mathrm{~Hz}$ で同時計測を行った。 計測されたデータには，電気的なノイズが混入してい るため, バンドパスフィルタ $(0.5-20 \mathrm{~Hz})$ を通してノイズ処 理を行い, その後3個の圧力計の波形を平均して, この 圧力データを計算值との比較に使用した。

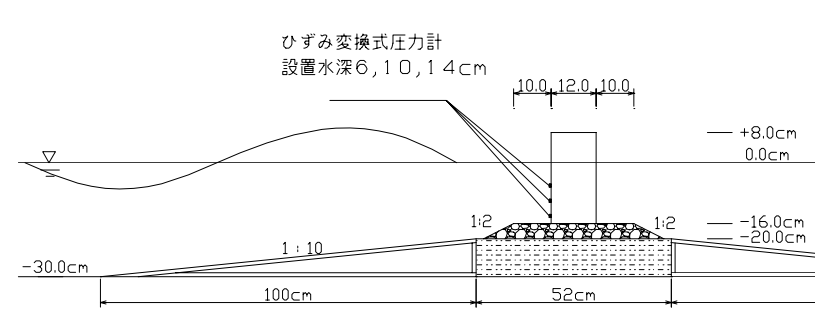

図-3 防波堤模型と圧力計の設置状況 


\section{(3) 波圧に及ぼす天端高の影響について}

実験で使用した模型ケーソンの天端高は現地換算で $8 \mathrm{~m}$ と十分な高さを確保しているが，波浪条件によって は越波が生じる場合がある。このため, 越波の発生した 場合と越波の発生していない場合では，波圧分布に相違 が生じることが予想される．有限振幅波重複波理論は天 端が半無限に続いていると仮定した場合の理論であり， そのため越波が発生した場合には計算精度が十分に確保 されない可能性も考えられる。しかし，伊藤ら 波領域において天端高が波圧分布に与える影響が小さい ことを実験により示しており，合田・福森”も越波による 波圧変化は実用上無視するのが妥当であると述べている． 従って, 本研究では天端高が圧力分布に及ぼす影響は無 視できると考えて, 以下に示寸実験值と計算值の比較を 行うこととする.

\section{4. 第4次近似解の波圧推定精度の定量的評価}

ここでは，実験值との比較に基づいて，波圧の計算精 度についての検討を行う。まず，図-4に圧力の実験值と 第4次近似解に基づく計算值の比較の一例を示寸. ここ では, 参考のために線形理論から求まる波圧についても あわせてプロットしている．第4次近似解の計算結果は, 圧力の最大, 最小值に加えて, その時間変化についても 実験結果とよく一致している．その他の波浪ケースにお いても，水深や個々の波ごとには若干のばらつきが観察 されるものの, 全体的に第4次近似解と実験結果との一 致は十分に高いと判断することができた.

次に, 第4次近似解と実験值との平均的, 全体的な相 関の程度を確認するため，横軸に波形勾配，縦軸に実験 值と第4次近似解の比を示した検討結果を図-5に示す. ここで，実験值 $\bar{p}_{\text {exp }}$ は，造波開始後の立ち上がり部分 のデータを取り除き，また造波板からの再反射波の影響 を受けていない合計10波の波を抽出して, 各波の波圧最 大值の10波平均值を実験波圧の代表値として使用した. この際，データ中に明らかに不自然と考えられるノイズ 等が混入している場合は除外し, 最終的に合計 68 データ を有効なデータと判断して使用した.

全体的な傾向としては, 縦軸 $\bar{p}_{\text {exp }} / p_{c a l}$ の值は横軸の 波形勾配の変化にはあまり影響を受けず，また水深に関 しては深くなるにつれて縦軸 $\bar{p}_{\exp } / p_{c a l}$ の值が若干小さ くなっていく傾向が観察される. その相違は水深 $6 \mathrm{~cm}$ $14 \mathrm{~cm}$ での縦軸 $\bar{p}_{\exp } / p_{c a l}$ の平均值の差で $8 \%$ 程度である. また，平均的には実験值の方が若干小さめの值を示して いるが，両者は最大でも $\pm 30 \%$ 以内の相違であり，統計 的なばらつきを考慮することで第4次近似解を使用した 波力の推定が可能であると考えられる.
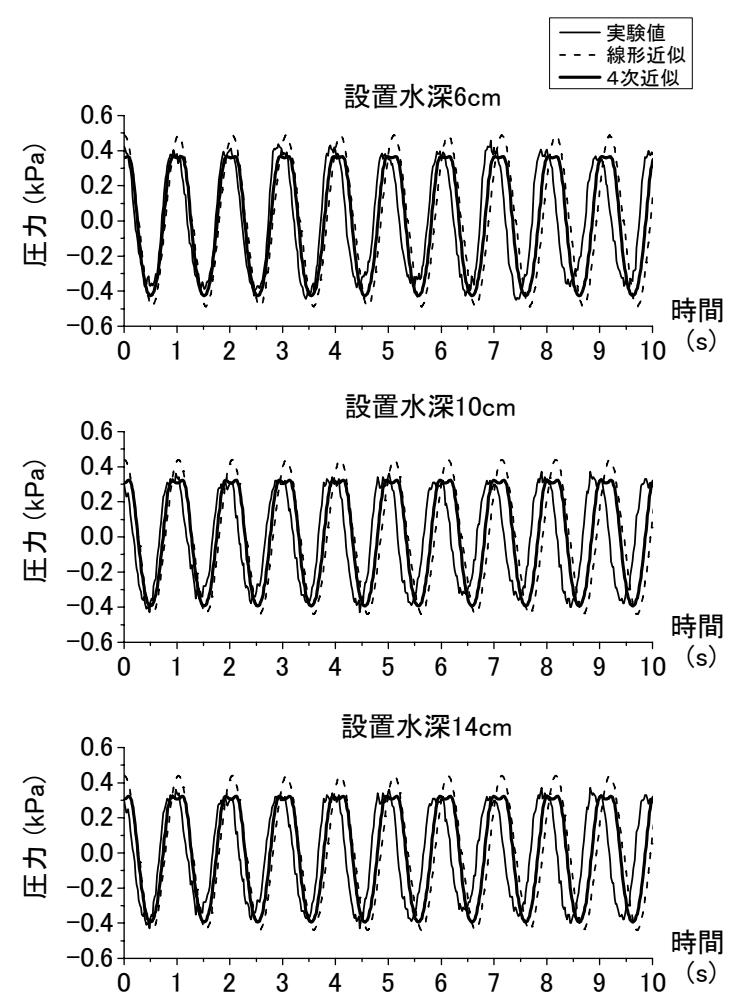

図-4 実験值と計算值の圧力変化の比較例 $(H=6 \mathrm{~cm}, T=1 \mathrm{~s})$

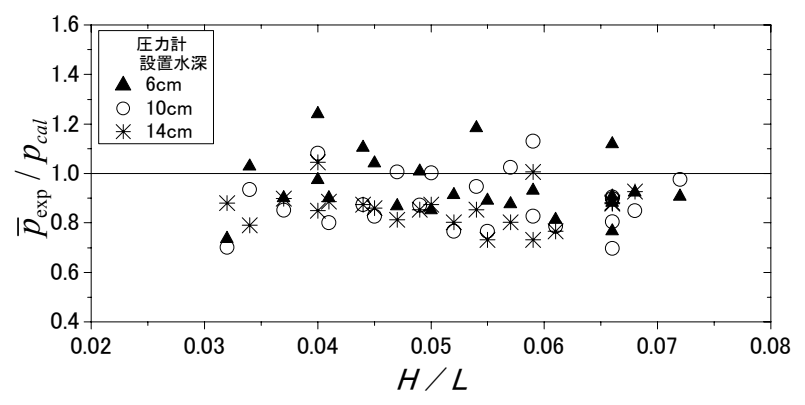

図-5 全検討ケースに対する波圧実験值と計算值の比較

計算値の精度を考える際, 実用上重要となる観点は, 第1に計算の結果が十分に信頼できるかという点，第2に 計算值と害際の圧力の間の定量的な関係性の点にあると 考えられる.ここで, 信頼性設計法を念頭においた場合 では，第2点目に関しては，平均的な関係性に加えて， 両者のばらつきの程度も重要となってくる. 図-5の結果 より判断すると, 実験值と計算值の関係性は, 実用上は それぞれの比 $\left(\bar{p}_{\text {exp }} / p_{c a l}\right)$ の平均值と標準偏差によっ て定量的に表現できると予想される，そこで，図-5で使 用した全データを使用して統計処理を実施した結果, $\bar{p}_{\text {exp }} / p_{\text {cal }}$ の平均値 0.91 , 標準偏差0.10を得た. ここで全 データを使用する理由は, 設計で最も重要となる防波堤 に作用する波力は上層から下層までの波圧の積分值であ るためである. また, 図-6に $\bar{p}_{\text {exp }} / p_{\text {cal }}$ の頻度分布と上 記の平均值と標準偏差の 2 母数を持つ正規分布を同時に 


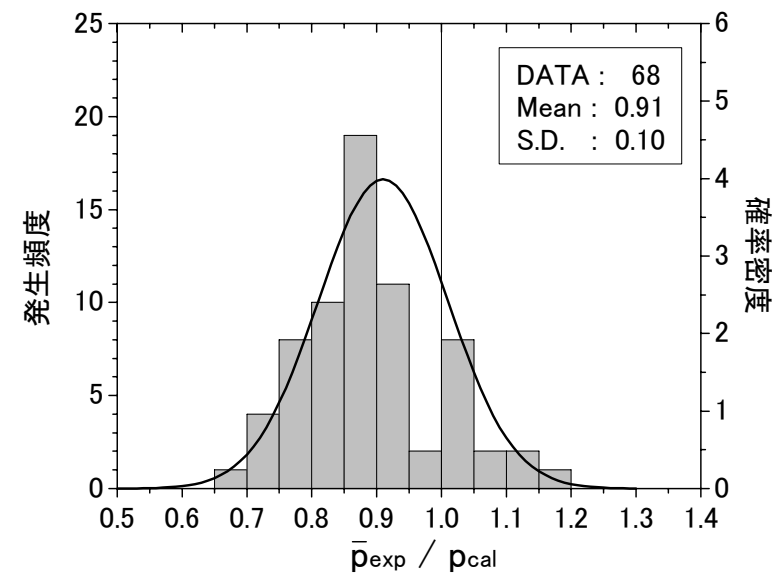

図-6 有限振幅重複波理論の第4次近似解の波圧推定精度

示す. 結果的には，第4次近似解の推定精度は正規分布 でも近似可能であると判断できる.

なお，高山ら ${ }^{10)}$ が合田の波力算定式に対して使用した

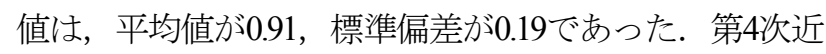
似解の推定精度と比較すると平均值は同程度であるが, ばらつきはかなり大きい，但し，以下の点に注意すべき である.すなわち，合田の波力算定式は，砕波から重複 波圧までを統一的に表現することのできる実用上極めて 有意義な評価式であるが，砕波と重複波では物理現象が 大きく異なるため, 波圧の推定精度は砕波時と重複波時 では大きく異なるはずである．高山らが使用した推定精 度は，この砕波と重複波の両者が混在したときの值を示 しているものと考えられる. 従って, 理論的な取り扱い が砕波に比べて随分と容易な重複波のみを考えた場合で は，合田の波力算定式の標準偏差は0.19よりも小さな值 に落ち着くと推測される.

\section{5. 結論}

本研究では，大水深に設置される防波堤に作用する支
配的な外力である重複波圧に着目して, その有力な推定 手法と期待される有限振幅重複波理論に基づく第4次近 似解の推定精度の定量的な評価を試みた。その結果，実 験值と計算值の比は平均 0.91 , 標準偏差 0.10 という変動 特性值が得られ，また両者の関係性は正規分布で近似可 能であることがわかった.

以上の変動特性值や分布形を信頼性設計法の中で適切 に使用することで，今後の大水深域に設置する防波堤等 海岸・海洋構造物の合理的な設計のための一助となるこ とを期待する.

\section{参考文献}

1) 下迫健一郎，高橋重雄 : 混成防波堤の期待滑動量の計算，海 岸工学論文集, 第 41 巻, pp.785-760, 1994.

2) 合田良実, 高木泰士 : 信頼性設計法におけるケーソン式防波 堤設計波高の再現期間の選定，海岸工学論文集，第 46 巻, pp.921-925, 1999.

3) 高木泰士，柴山知也：大水深地点におけるケーソン式防波堤 の信頼性設計手法の提案, 海岸工学論文集, 第 53 巻, pp.901-905, 2006.

4) 合田良実，杮崎秀作 : 有限振幅重複波ならびにその波圧に関 する研究，港湾技術研究所報告，第 5 巻，第 10 号，pp.1-49, 1966.

5) Tsuchiya, Y., Yamaguchi, M. : Limiting condition for standing wave theories by perturbation method, Proc. 12th Int. Conf. Coastal Eng., ASCE, pp.523-542, 1970.

6) Mallayachari, V., Sundar, V. : Standing wave pressures due to regular and random waves on a vertical wall, J.Ocean Engng., Vol.22, No.8, pp.859$879,1995$.

7) Nagai, S. : Pressures of standing waves on vertical wall, J. Waterway and Harbour Division, ASCE 95, pp.53-76, 1969.

8) 伊藤喜行, 藤島睦, 北谷高雄 : 防波堤の安定性に関寸る研究, 港湾技術研究所報告，第 5 巻，第 14 号，pp.1-133， 1966.

9) 合田良実，福森利夫 : 直立壁および混成堤直立部に働く波圧 に関する実験的研究，港湾技術研究所報告，第 11 巻，第 2 号, pp.3-45, 1972.

10) 高山知司，鈴木康正，河合弘泰，藤咲秀可 : 防波堤の信頼 性設計に向けて，港湾技術研究所資料，No.785，36p., 1994.

(2007.5.9 受付)

\section{ESTIMATION ERROR IN THE ANALYTICAL PREDICTION OF STANDING WAVE PRESSURES ACTING UPON BREAKWATERS}

\section{Hiroshi TAKAGI and Chihiro NAKAJIMA}

The standing wave pressure is the predominant force in designing deepwater breakwaters. When the design of breakwaters is conducted by means of the reliability based design, some values denoting the reliability of the quantitative estimation of the standing wave pressures will be required in order to obtain a reasonable dimension for the breakwater. In the present study, a comparison between the computed results using the forth order approximation based on the finite amplitude theory and the experimental results is made to obtain those values. Consequently, both the bias of the experimental results with regard to the computational results $(=0.91)$ and the standard deviation $(=0.10)$ are found. 